\title{
Restructuring finance to promote productive employment
}

\author{
Gerald Epstein* \\ Professor of Economics and Co-Director, Political Economy Research Institute (PERI), University of \\ Massachusetts, Amherst, USA
}

Modern financial markets and institutions have grown massively in relation to the economy in the United States and elsewhere, and there is little evidence that in recent years their contributions to economic and social output justify the resources they capture and the risks they impose on society. Many policy options exist to limit finance's destructive excesses and to shrink its size. But while these efforts are important, more proactive measures to redirect financial activity is likely to be needed to achieve key social goals, such as employment generation and a successful transition to a fossil fuel limited economy. Refocusing financial institutions and financial activities toward providing investments in renewable energy and energy conservation provide an important example of reformed financial activity that both generate more and decent employment, while contributing to the production of key social goods. Abandoning the decades-long embrace of speculative finance and promoting socially efficient finance instead is a key imperative facing the United States and many other countries who adopted financial liberalization in the late twentieth century, with costly results.

Keywords: financialization, employment, green transformation

JEL codes: $E 24, E 6, G 1, Q 54$

\section{INTRODUCTION $^{1}$}

The Great Financial Crisis of 2008 has called into question the contributions of modern financial institutions and practices to social well-being, as distinct from the well-being of the banks' or their CEOs' bottom lines. Recent research has cast serious doubt on previous findings of a uniformly positive relationship between the size of the financial system and economic growth (see, for example, Arcand et al. 2012; Cecchetti/Kharroubi 2012; Sturn/Epstein 2013). Others have identified a decline in the efficiency of the financial sector even as it has grown so large (Philippon 2012; Epstein/Crotty 2013; Greenwood/ Scharfstein 2013). The increase in the size of finance is one manifestation of the more general phenomenon of financialization which has been associated with economic difficulties and crisis (Stockhammer 2004; Orhangazi 2011; Hein 2012; Palley 2013). A chorus of regulators and economists have decried the problems associated with too-big-to-fail banks, and bloated bankers and banker bonuses (Turner 2009; Volcker 2009).

* I thank Joao Paulo de Souza, Iren Levina, Juan Montecino, and Simon Sturn for their research contributions on which some of this paper is based. I also thank Robert Pollin and Heidi GarrettPeltier for sharing their work on employment and renewable energy, and James Crotty for helpful discussions on financial issues. Finally, I thank the Institute for New Economic Thinking (INET) for financial support.

1. Some of the material in this article draws on Epstein (2013). 
This concern about the social efficiency of finance is not a completely new one, though it has gained increased force as a result of the financial crisis of 2007-2008. The late Nobel Prize winner, James Tobin, raised early concerns about the growth and social efficiency of the financial sector: his important essay, 'On the efficiency of the financial sector,' first published in Lloyd's Bank Review in 1984, defined four different types of efficiency of the financial system. Regarding the fourth concept of financial efficiency, Tobin (1984: 3, author's italics) writes: 'The fourth concept relates ... to the economic functions of the financial industries ... These include: the pooling of risks and their allocation to those most able and willing to bear them ... the facilitation of transactions by providing mechanisms and networks of payments; the mobilization of saving for investments in physical and human capital ... and the allocation of saving to their more socially productive uses. I call efficiency in these respects functional efficiency'. Tobin (ibid.: 14) goes on to write: 'I confess to an uneasy Physiocratic suspicion, perhaps unbecoming in an academic, that we are throwing more and more of our resources, including the cream of our youth, into financial activities remote from the production of goods and services, into activities that generate high private rewards disproportionate to their social productivity'.

Indeed, one could do a back-of-the-envelope calculation of the recent practices of the functional efficiency, to use Tobin's term, of the global financial system: When all is said and done, the global financial crisis - instigated by banks, hedge funds, and other financial institutions - will cost the world economy in terms of lost jobs and economic output somewhere between 60 and 200 trillion dollars. That is from Andrew Haldane of the Bank of England (Haldane 2010.)

We are living in a financialized capitalism, a capitalism where our large financial system has a major impact on our lives and livelihood. For several decades, this financialized capitalism has been locked in a devastating dynamic of deregulation, financial innovation, financial crash, and government bail-out (Crotty 2009). Then the cycle starts over again with bailed-out banks and bank CEOs and 'rainmakers' more emboldened to lend more and take on more risks in the future. The result has been an ever-expanding financial sector in many of the world's richest countries. In the United States, the total financial assets have grown from four times the size of GDP in 1945 to 10 times GDP in 2008. This growth has been accompanied by a startling increase in profits in the financial sector in the US. By 2006, just before the crash, financial sector profits constituted a full 40 percent of total domestic profits in the United States (Epstein/Crotty 2013).

We witnessed similarly large increases in the size and profitability of the financial sector in the UK and in several other European countries. Accompanying this massive increase in the size and profitability of finance has been a dramatic increase in inequality in the US, UK, and some other heavily financialized economies (Stockhammer 2004; Hein 2012; Lapavitsas 2013). It seems reasonable to ask, as did Tobin and more recent observers, what are the social contributions that this large and highly expensive financial sector make to society? Is finance worth all the toil and trouble?

\section{THE CONTRIBUTIONS OF FINANCE TO SOCIETY: A CLOSER LOOK}

What are the contributions of this massive financial sector to society? We know that the massive costs of the current financial crisis suggest that the contributions of a massive financial sector - on balance - are questionable at best. But perhaps, over the long run, more finance contributes to more rapid economic growth and other social benefits. Is this true?

It is hard to find evidence of this result in the data. Figure 1, due to Philippon, shows that, looking over a 150-year time-span in the US - 1860-2010 - there is no apparent 


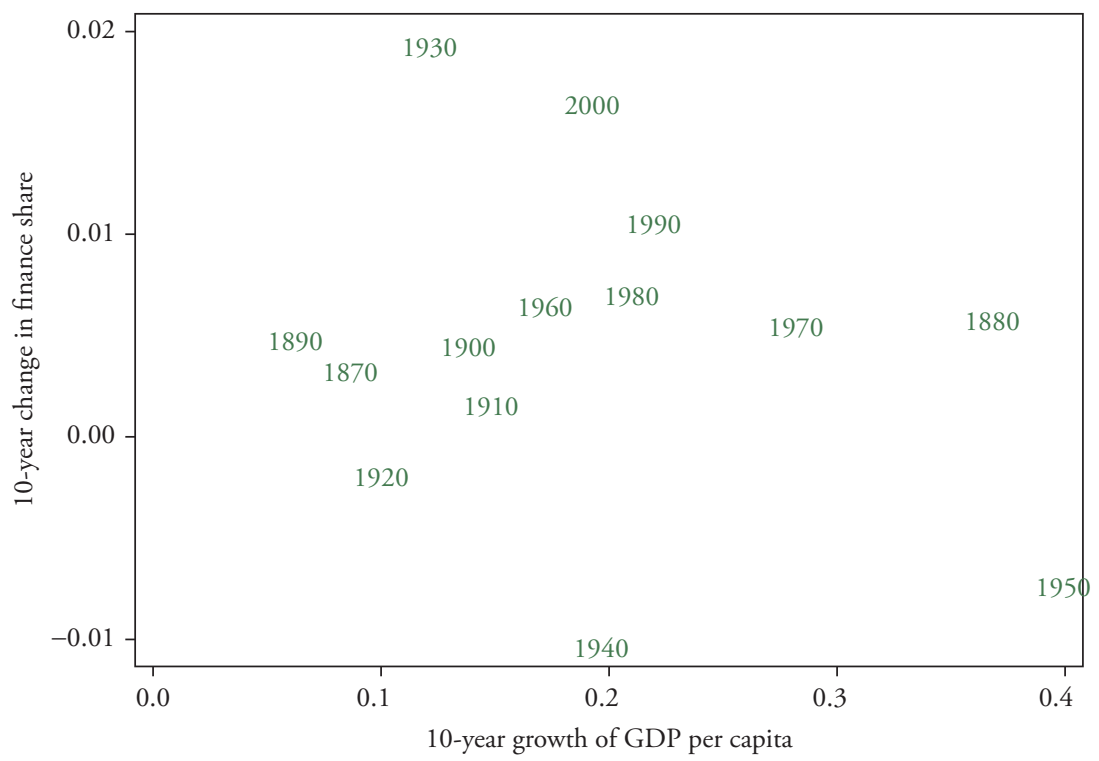

Source: Philippon (2012).

Figure 1 Financial income and economic growth in the United States, 1860-2010

relationship between the share of national income going to financial business and the rate of economic growth in the United States.

Now it is somewhat surprising that we cannot identify a clearer connection between financial activity and positive economic outcomes, such as economic growth. It is surprising because a properly functioning financial system has a lot to contribute to the health of the economy. Josef Schumpeter emphasized the key role that banking played for real investment and economic innovation. And, as James Tobin suggested, the positive roles potentially played by the financial system are numerous, including, among others:

- Channeling finance to productive investment

- Providing mechanisms for households to transfer income over time

- Helping families and businesses to reduce risk (risk sharing)

- Helping provide stable and elastic liquidity to households and businesses

- Developing new, useful financial innovations.

So, if the financial system is fulfilling these functions, it should be leading to a healthier economy, should it not? Should it not be contributing more to visible outcomes such as economic growth?

The puzzle is solved, however, when we look at how our actually existing financial system has been handling all of these important functions.

\subsection{Channeling finance to productive investment}

The first and perhaps most important functions of the financial sector are to mobilize and channel financial resources to productive investment, since productive investment is a key driver of employment and productivity growth in the economy. But, as 
Table 1 Net borrowing by non-financial corporations and capital expenditures in six financial centers

\begin{tabular}{lccc}
\hline & Period & $\begin{array}{c}\text { Net borrowing } \\
\text { capital expenditures) }\end{array}$ & $\begin{array}{c}\text { Capital expenditures } \\
\text { (\% of GDP) }\end{array}$ \\
\hline United States & $1947-1965$ & 9.1 & 10.0 \\
& $1966-1981$ & 21.2 & 11.9 \\
& $1982-2007$ & 6.9 & 10.3 \\
United Kingdom & $2008-2011$ & -25.9 & 8.3 \\
Germany & $1990-2002$ & 0.6 & 10.9 \\
& $2003-2011$ & -37.4 & 9.1 \\
The Netherlands & $1995-2001$ & 11.7 & 11.5 \\
& $2002-2011$ & -9.3 & 10.2 \\
Switzerland & $1980-1993$ & -8.7 & 10.8 \\
France & $1994-2001$ & -31.4 & 8.8 \\
& $2002-2011$ & -86.7 & 13.1 \\
& $1995-2002$ & 4.3 & 10.4 \\
& $2003-2011$ & -25.6 & 9.3 \\
& $1971-1975$ & 41.8 & 9.9 \\
& $1976-1985$ & 52.9 & 8.4 \\
\hline
\end{tabular}

Source: De Souza/Epstein (2014).

Table 1 indicates, in recent years finance has been providing a decreasing share of the financial resources used by non-financial corporations in relation to their capital investment needs. The so-called 'financing gap' - the gap between investment resources needed and those available from corporate saving - has been narrowing in the US (and in the UK and several European countries) relative to the amount invested in capital equipment and factories.

If the financial sector has not been lending as much as previously to non-financial corporations for investment, what have they been doing? For one thing, they have lent a large amount of credit to households in the build-up to the destructive housing and real-estate bubbles in the US, UK, and elsewhere. In addition, banks have simply been lending increasing amounts to each other, as the financial sector has engaged in massive amounts of 'proprietary trading' and gambling as they have tried to build up their income and bonus pools for their traders. Figure 2 shows estimates of the share of lending by financial institutions to each other in the build-up to the economic crisis in the US. We see a similar build-up in the UK and some other European countries as well (Montecino et al. 2014).

\subsection{Providing mechanisms for households to transfer income over time and helping families and businesses to reduce risk (risk sharing)}

The financial sector has not performed well as a mechanism helping households save for retirement. For starters, the Great Financial Crash of 2008 wiped out $\$ 16$ trillion of household wealth in the US between 2007 and 2009, of which only about 45 percent might have been restored since that time (Luttrell et al. 2013). The near-zero interest rates fostered by central banks in the aftermath of the crisis have also significantly reduced the returns earned by savers in fixed income type securities; and evidence indicates that the 


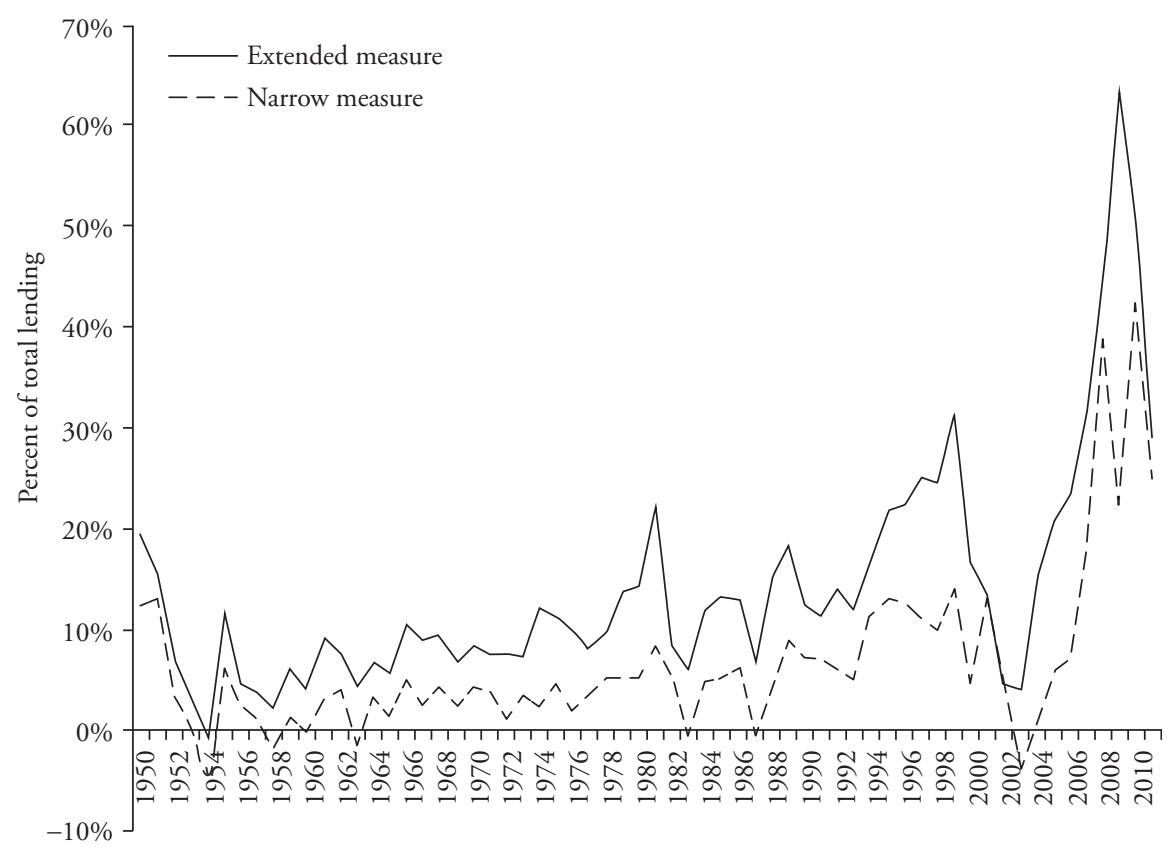

Source: Montecino et al. (2014).

Figure 2 Financial sector lending to itself as share of total lending, US, 1950-2010

financial advising and management services industry that manages wealth in the US and elsewhere earns high management fees for relatively poor investment returns relative to much simpler self-designed financial strategies (Greenwood/Scharfstein 2013). And private pension funds have performed rather poorly for most Americans (Schultz 2011). In short, the financial system has done a poor job of helping households provide for their retirement.

\subsection{Helping provide stable and elastic liquidity to households and businesses}

The financial crisis has clearly demonstrated the illusion of appropriate liquidity provision by the financial system to households and businesses. In the build-up to the financial crisis, the financial sector provided massive amounts of liquidity (credit) to households and businesses that fostered housing and real-estate bubbles and to financial institutions that were bundling, packaging, and selling off complex and ultimately toxic securities. But when the bubble burst and banks tried to dump as many of these dodgy securities as possible, liquidity in the market dried up, and few buyers could be found for these questionable assets. As their values collapsed, banks tottered on the edge of bankruptcy, requiring bailouts from taxpayers, and then banks tightened credit conditions to protect their resources, drying up liquidity for households and businesses that were trying to refinance houses and maintain their businesses (Crotty/Epstein 2014).

In short, the highly financialized and speculative financial system has proven to be a poor provider of appropriate and predictable liquidity. 


\subsection{Developing new, useful financial innovations}

Financial innovations, such as collateralized debt obligations, were at the center of the financial crisis of 2007-2008 (Jarsulic 2012). More generally, studies of financial innovations have been unable to find any connection between financial innovation and economic growth. As Crotty/Epstein (2009) show in a review of studies from the 1980s-1990s, 30-40 percent of financial innovations in the US are undertaken for tax or regulatory avoidance rather than to reduce costs facing customers or to enhance the quality of the products for end users. In short, these innovations simply redistribute the economic pie, rather than increase its size, and are therefore not socially useful or functionally efficient. Financial innovations offer a lot of promise, but, it appears, deliver few results.

\section{RESTRUCTURING FINANCE TO PROVIDE PRODUCTIVE EMPLOYMENT}

If the current financial system uses up too many resources, raises too many risks for the health of the economy, and in return, provides too little in the way of social benefits, then how can it be restructured to be more socially useful? Details are important, and there are significant differences across different countries. To make these suggestions concrete, therefore, I will refer mostly to the United States in what follows.

What is the current policy in the US and Europe for dealing with their risky and inefficient financial systems? Financial reform policies have been stalled and in some cases rolled back since the initial impetus of the crisis has now faded, while the bank lobbyists, spending many millions of dollars, have been able on both sides of the Atlantic to impede genuine reform (Epstein/Habbard 2013). To the extent that a reform policy has been implemented, it has primarily involved the following components: increases in bank capital requirements; some increase in leverage requirements; and some attempts to limit risky activities by financial institutions with public safety nets (that is, the Volcker Rule, in the US). While a number of these initiatives have some promise, none of these rules is stringent enough to significantly limit the size of financial institutions or the financial sector overall, and it is doubtful that they are sufficiently effective in limiting overall risk.

Other policies are available that could limit and even reduce the size of the financial sector. These include a significant financial transactions tax (Pollin 2012a); a bank profit tax; and a limit on the asset or liability size of financial institutions (Eavis 2012).

While reducing or limiting the size of financial institutions might play an important role in limiting the excesses of finance, or might create the potential for re-allocating resources to more socially beneficial uses - including employment generation - this will not be sufficient to do so. The financial institutions themselves will have to be re-oriented to play a more socially productive role.

One set of approaches is to implement what Epstein et al. (2009) referred to as more 'finance without financiers': that is, more public and cooperative forms of financial institutions that are dedicated to serving specific social needs. These could include the financing of cooperative enterprises, public infrastructure, social goods such as housing for the poor and homeless, and of small business and community owned institutions including those in the agricultural sector. Epstein (2010) discusses some concrete examples of this approach; also see Moseley (2013) for a discussion of bank nationalization as an approach. As we discuss further below, these institutions can also be used to generate more employment in a variety of sectors, including renewable and fossil-free energy sources.

As history has shown, such public, cooperative, and specialized institutions can be highly effective, but they can also be perverted by many of the same forces that can 
lead private financial institutions to engage in destructive behavior. The involvement of some German public institutions, some Landesbanks, in the sub-prime mortgage disaster in the United States is an example of this distorted and destructive behavior. As a result, such public and cooperative financial institutions will not be a panacea to the problems the speculative financial behemoths have created. Still, properly incentivized, regulated, and managed, they can play an important role in promoting a more productive financial structure.

\subsection{Financial tools to promote green employment}

As an important concrete example of employment generation programs, in this section I discuss financial mechanisms for generating more employment in the renewable energy sector. $^{2}$

Apart from restructuring or inventing financial institutions, creative policy tools can be wielded by central banks and other state institutions to promote more productive employment. The central bank and Treasury Department, for example, can provide lines of credit and seed capital to institutions that specialize in the financing of renewable energy projects. The Central Bank can impose Asset Backed Reserve Requirements to induce banks to invest in renewable energy projects (Palley 2005; Pollin 2012b). The central bank or Treasury can also provide loan guarantees for renewable energy companies (Pollin 2011; Pollin et al. 2011). The latter were tried with some success (and some failures) in President Obama's stimulus package in 2009, and some of these efforts continue. But they have to be significantly expanded if they are to generate the investments needed to address climate change, or generate significant levels of employment in these areas.

As Pollin and his collaborators have shown, the potential clearly exists for investments in renewable energy production and conservation efforts to generate significant numbers of decent, new jobs.

Figure 3 shows the number of new jobs that can be created with a billion dollars in new investments in renewable energy or energy conservation. These employment numbers are compared with the number of jobs created by spending $\$ 1$ billion on the military, oil/gas production, and other activities.

Table 2 summarizes the results. A billion-dollar investment in 'clean energy' will generate 17100 new jobs, whereas the same investment will generate only 11600 jobs in the military or 5180 in oil and gas production.

What types of jobs are these? Pollin et al. (2011) show that a broad range of types of jobs are created by expanding these industries, from entry level type jobs to jobs requiring much more skill and experience. They see this range as a positive factor, in that these jobs will be available for a broad cross-section of society.

One might argue that the types of restructuring of finance and credit allocation tools discussed above are unnecessary to achieve these goals of green transformation - that 'modern' financial markets are very useful in facilitating 'cap and trade' approaches to limiting greenhouse gases from fossil fuels. Through the use of derivatives and other complex financial engineering, a synergy is created between large financial institutions and the generation of renewable energy and green jobs.

2. This section draws heavily on the extensive work of my colleague Robert Pollin and collaborators, including James Heintz, Heidi Garrett-Peltier, and Jeannette Wicks-Lim. See Pollin (2011; 2012b); Pollin/Garrett-Peltier (2011; 2012); and Pollin, Heintz, Garett-Peltier and Wicks-Lim (2011). 


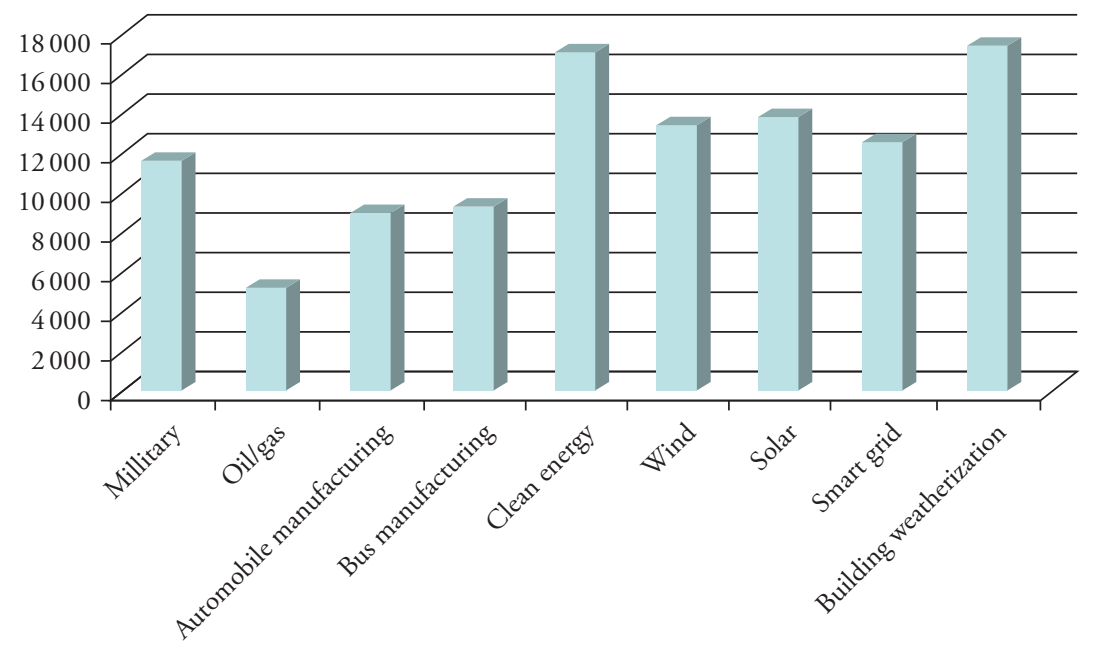

Source: Political Economy Research Institute and IMPLAN.

Figure 3 Number of new jobs that can be created with $\$ 1$ billion

Table 2 Jobs per $\$ 1$ billion direct spending

\begin{tabular}{lc}
\hline Sector & $\begin{array}{c}\text { Jobs per } \$ 1 \text { billion } \\
\text { of direct spending }\end{array}$ \\
\hline Military & 11600 \\
Oil/gas & 5180 \\
Automobile manufacturing & 8960 \\
Bus manufacturing & 9240 \\
Clean energy $^{\mathrm{a}}$ & 17100 \\
Within clean energy: & 13300 \\
Wind & 13720 \\
Solar & 12460 \\
Smart grid & 17360 \\
Building weatherization &
\end{tabular}

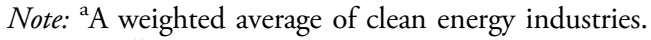

Source: Pollin/Garrett-Peltier (2011).

But, as Boyce/Riddle (2007) and others have argued, these 'cap and trade' policies have done more to generate rents for utility companies and financial engineers than they have for limiting fossil fuel consumption. A better approach is to use financial institutions to facilitate the production of renewable production directly, and limit speculative trading in climate assets.

\section{CONCLUSION}

Modern financial markets and institutions have grown massively in relation to the economy, and there is little evidence that in recent years their contributions to economic and social output justify the resources they capture and the risks they impose on society. Many 
policy options exist to limit finance's destructive excesses and to shrink its size. But while these efforts are important, more proactive measures to redirect financial activity are likely to be needed to achieve key social goals, such as employment generation and a successful transition to a fossil fuel limited economy.

Refocusing financial institutions and financial activities toward providing investments in renewable energy and energy conservation give an important example of reformed financial activity that both generate more and decent employment, while contributing to the production of key social goods. Abandoning the decades-long embrace of speculative finance, and embracing socially productive finance instead, seems like a desirable path for economists to invest more time in studying and for policy-makers and activists to consider.

\section{REFERENCES}

Arcand, Jean-Louis, Berkes, Enrico, Panizza, Ugo (2012): Too much finance? IMF Working Paper, No. $12 / 61$.

Boyce, James K., Riddle, Matthew (2007): Cap and dividend: how to curb global warming while protecting the incomes of American families, PERI Working Paper, No. 150, November.

Cecchetti, S., Kharroubi, E. (2012): Reassessing the impact of finance on growth, Bank for International Settlements working paper, No. 381.

Crotty, James (2009): Structural causes of the global financial crisis: a critical assessment of the 'New Financial Architecture,' in: Cambridge Journal of Economics, 33(4), 563-580.

Crotty, James, Epstein, Gerald (2009): Avoiding another meltdown, in: Challenge Magazine, JanuaryFebruary, 5-26.

Crotty, James, Epstein, Gerald (2014): The last refuge of scoundrels: Keynes-Minsky perspectives on the uses and abuses of the 'liquidity defense,' in: Epstein, Gerald, Schlesinger, Tom, Vernengo, Matias (eds), Financial Institutions, Global Markets, and Financial Crisis: Essays in Honor of Jane Webb D'Arista, Cheltenham, UK and Northampton, MA: Edward Elgar, 319-350.

De Souza, Joao Paulo A., Epstein, Gerald (2014): Sectoral net lending in six financial centers, PERI Working Paper.

Eavis, Peter (2012): Fed governor's plan to limit bank size fuels debate, in: The New York Times, 15 October.

Epstein, Gerald (2010): Finance without financiers: prospects for radical change in financial governance: David Gordon Memorial Lecture, in: Review of Radical Political Economics, 42(3), 293-306.

Epstein, Gerald (2013): Restructuring finance to better serve society, in: Palley, Thomas I., Horn, Gustav (eds), Restoring Shared Prosperity: A Policy Agenda from Leading Keynesian Economists, 87-96, URL: http://www.thomaspalley.com/docs/research/restoring_shared_prosperity.pdf.

Epstein, Gerald, Crotty, James (2013): How big is too big? On the social efficiency of the financial sector in the United States, in: Pollin, Robert, Wicks-Lim, Jeannette (eds), Capitalism on Trial: Explorations in the Tradition of Thomas Weisskopf, Cheltenham, UK and Northampton, MA: Edward Elgar, 293-310.

Epstein, Gerald, Habbard, Pierre (2013): Speculation and sovereign debt - an insidious interaction, in: Wolfson, Martin, Epstein, Gerald (eds), Handbook of the Political Economy of Financial Crisis, Oxford: Oxford University Press, 326-356.

Epstein, Gerald, Plihon, Dominique, Giannola, Adriano, Weller, Christian (2009): Finance without financiers, in: Papers of Europe, special issue on the Financial Crisis, Summer, URL: http://www. ucm.es/info/icei/.

Greenwood, Robin, Scharfstein, David (2013): The growth of finance, in: Journal of Economic Perspectives, Spring, 3-28.

Haldane, Andrew (2010): The 100 billion dollar question, Bank of England, March, URL: http:// www.bankofengland.co.uk/publications/speeches/2010/speech433.pdf.

Hein, Eckhard (2012): The Macroeconomics of Finance-dominated Capitalism - and its Crisis, Cheltenham, UK and Northampton, MA: Edward Elgar. 
Jarsulic, Marc (2012): Anatomy of a Financial Crisis: A Real Estate Bubble, Runaway Credit Markets, and Regulatory Failure, New York: Palgrave Macmillan.

Lapavitsas, Costas (2013): Profit without Production, London: Verso Press.

Luttrell, David, Atkinson, Tyler, Rosenblum, Harvey (2013): Assessing the costs and consequences of the 2007-09 financial crisis and its aftermath, in: Dallas Federal Reserve Economics Letter, September.

Montecino, Juan Antonio, Epstein, Gerald, Levina, Iren (2014): Long-term trends in intra-financial sector lending in the U.S.: 1950-2012, PERI Working Paper, No. 344.

Moseley, Fred (2013): The bailout of the 'too-big-to fail' banks: never again, in: Wolfson, Martin H., Epstein, Gerald (eds), The Handbook of the Political Economy of Financial Crises, New York: Oxford University Press, 624-644.

Orhangazi, O. (2011): 'Financial' vs. 'real': an overview of the contradictory role of finance, in: Research in Political Economy, 27, 121-148.

Palley, Thomas I. (2005): A Post Keynesian framework for monetary policy: why interest rate operating procedures are not enough, in: Gnos, C., Rochon, L.-P. (eds), Post Keynesian Principles of Policy, Cheltenham, UK and Northampton, MA: Edward Elgar, 81-101.

Palley, Thomas I. (2013): Financialization: The Economics of Finance Capital Domination, London: Palgrave Macmillan.

Philippon, T. (2012): Has the US finance industry become less efficient? On the theory and measurement of financial intermediation, National Bureau of Economic Research Working Paper, 18077.

Pollin, Robert (2011): A policy framework for advancing productive investments and clean energy throughout the US economy, Report, PERI.

Pollin, Robert (2012a): A U.S. financial transactions tax: how Wall Street can pay for its mess, in: New Labor Forum, Spring, 96-99.

Pollin, Robert (2012b): The great U.S. liquidity trap of 2009-2011: are we stuck pushing on strings? PERI Working Paper, No. 284, June.

Pollin, Robert, Garrett-Peltier, Heidi (2011): The US employment effects of military and domestic spending priorities: 2011 update, Report, PERI.

Pollin, Robert, Garrett-Peltier, Heidi (2012): Benefits of a slimmer Pentagon, in: The Nation Magazine, 28 May, $15-18$.

Pollin, Robert, Heintz, James, Garrett-Peltier, Heidi, Wicks-Lim, Jeannette (2011): 19 million jobs for U.S. workers: the impact of channeling $\$ 1.4$ trillion in excess liquid asset holdings into productive investments, Report, PERI.

Schultz, Ellen E. (2011): Retirement Heist: How Companies Plunder and Profit from the Nest Eggs of American Workers, New York: Portfolio/Penguin.

Stockhammer, E. (2004): Financialisation and the slowdown of accumulation, in: Cambridge Journal of Economics, 28(5), 719-741.

Sturn, Simon, Epstein, Gerald (2013): Finance and growth: the neglected role of the business cycle, PERI Working Paper, No. 339.

Tobin, James (1984): On the efficiency of the financial system, in: Lloyds Bank Review, July, pp. 1-15.

Turner, Adair (2009): Mansion House speech, 22 September, URL: http://www.fsa.gov.uk/pages/ Library/Communication/Speeches/2009/0922_at.shtml.

Volcker, Paul (2009): 'Wake up, gentlemen', world's top bankers warned by former Fed chairman Volcker, in: The Times, London, 9 December. 